\title{
The effect of enamel matrix derivative (EMD) in combination with deproteinized bovine bone material (DBBM) on the early wound healing of rabbit calvarial defects
}

\author{
You-Seok Kim ${ }^{1}$, Hyun-Seon Jang ${ }^{1,4}$, Ju-Chol Park ${ }^{2,4}$, Heoung-Jung Kim ${ }^{3,4}$ \\ Jong-Woo Lee ${ }^{1}$, Chong-Kwan Kim ${ }^{5,6}$, Byung-Ock Kim ${ }^{1,4}$ \\ Dept. of Periodontology, College of Dentistry, Chosun University ${ }^{1}$ \\ Dept. of Oral Histology, College of Dentistry, Chosun University ${ }^{2}$ \\ Dept. of Oral Anatomy, College of Dentistry, Chosun University ${ }^{3}$ \\ Oral Biology Research Institute, Chosun University ${ }^{4}$ \\ Dept. of Periodontology, College of Dentistry, Yonsei University ${ }^{5}$ \\ Research Institute for Periodontal Regeneration, Yonsei University ${ }^{6}$
}

\begin{abstract}
I. Introduction
Implant insertion according to planned prosthetic position often causes the problem of an insufficient amount of host bone at the recipient site. The longterm prognosis of dental implants is adversely affected by an inadequate bone volume ${ }^{1)}$. Several methods have been described for the regeneration of lost alveolar bone: First, the principle of osteoconduction is executed by the use of filling materials that serve as a scaffold for new bone growth ${ }^{2)}$; Second, the principle of osteoinduction uses appropriate growth factors with the aim of inducing differentiation of mesenchymal stem cells to osteoblasts ${ }^{1,3)}$.

Grafting materials for osteoconduction served as a
\end{abstract}

scaffold for the ingrowth of capillaries, perivascular tissue, osteoprogenitor cells from the recipient beds $^{2)}$ and maintained mechanical stability and volume during the initial healing ${ }^{4-6)}$. Grafting materials are autogenous bone, synthetic materials, allografts, and xenografts. Autogenous bone is considered the "gold standard" for grafting oral bony defects ${ }^{7,8)}$.

One of the xenogenic materials, deproteinized bovine bone materials (Bio-Oss ${ }^{\circledR}$, Geistlich, Wolhusen/Switzerland) showed good clinical success and proven osteoconductive properties ${ }^{9-11)}$. Electron microscopic evaluation shows that this material has a structural configuration similar to human bone. Its compressive strength and modulus of elasticity are also similar to the values for human

\footnotetext{
*This study was supported by a grant of the Korea Health 21 R \& D Project, Ministry of Health \& Welfare, Republic of Korea (03-PJ1PG1-CH08-0001).

Corresponding author: Byung-Ock Kim, Department of Periodontology, College of Dentistry, Chosun University, 421 SeoseokDong, Dong-Ku, Gwang-ju, 501-759, Korea, Tel:+82-62-220-3856, Fax: +82-62-224-4664, E-mail: bobkim@chosun.ac.kr
} 
bone $^{12,13)}$. A number of studies have shown that the bone mineral particles were completely encapsulated in newly formed bone when they were used in combination with Guided bone regeneration for the reconstruction of bone defects around dental implants in dogs ${ }^{11)}$ or under nonpermeable silicone domes on the skull of rats ${ }^{14)}$.

Enamel matrix proteins are known to have important biologic roles in the formation of acellular cementum, periodontal ligament, and alveolar bone during tooth development ${ }^{15-19)}$. Based on this concept, a recently-developed porcine enamel matrix derivative (EMD) compound (Emdogain ${ }^{\mathbb{}}$, Biora, Inc., Sweden) has been suggested to encourage periodontal tissue regeneration such as activation of biosynthesis of cementum, periodontal ligament, and alveolar bone ${ }^{20-24)}$.

The bone tissue might also be influenced by EMD according to the observations reported at the histo$\operatorname{logic}{ }^{16)}$, clinical ${ }^{20.21)}$ and cellular levels ${ }^{27,28)}$. It has reported that EMD could effect early stages of osteogenic maturation by stimulating bone cell proliferation ${ }^{28}$. When used in combination with demineralized freeze-dried bone allograft (DFDBA) for heterotopic bone formation, it seemed to enhance the bone induction potential of DFDBA ${ }^{29}$. In vivo studies have demonstrated that EMD increase new trabeculae formation in rat long bone repair model ${ }^{30}$. EMD also has promoted repair of circular defects in rat parietal bone. More mineralized tissues were formed in the defects applied with EMD compared to carrier alone ${ }^{31}$. Osteoinductive proteins require a carrier material, which serve as a delivery system and as a scaffold for cellular ingrowth ${ }^{32)}$.

Enamel matrix derivative is already used clinical$1 y^{25,26)}$ however, little is known about bone formation effect of EMD. The aim of the present investigation was to evaluate the effect of enamel matrix derivative (EMD) in combination with deproteinized bovine bone materials (DBBM) on the early wound healing of rabbit calvarial defects.

\section{Material and Methods}

\section{Surgical protocol}

Nine New Zealand white male rabbits between 2.8 and $4 \mathrm{~kg}$ were included in this randomized, blinded, prospective study. Each rabbit was anesthetized with Ketamine $\mathrm{Hcl}(5 \mathrm{mg} / \mathrm{kg})$ and Xylazine $\mathrm{Hcl}(1.5 \mathrm{ml} / \mathrm{kg})$. The fur was shaved over the cranium, which was prepared and draped in a sterile fashion. An incision was made to the bony cranium and the periosteum was reflected. By means of a trephine bur (external diameter : $8 \mathrm{~mm}$ ). Four critical-sized defects (critical size being $15 \mathrm{~mm}$ wide) could not be created in the rabbit cranium because it is too small. Four non-critical sized $8 \mathrm{~mm}$ defects were created with copious irrigation. The four calvarial defects were randomly grafted with DBBM, DBBM with EMD, EMD alone, and no graft as a control. The Four defects were covered with nonresorbable PTFE membrane (Tefgen ${ }^{\circledR}$, Lifecore Biomedical, Inc, U.S.A.). The wound was closed with resorbable suture materials, and the rabbits were extubated and allowed to recover. At the end of the surgical procedure, all animals received a single intramuscular injection of Gentamicin $(0.1 \mathrm{ml} / \mathrm{kg})$

Rabbits were killed using phentobarbital (100mg/kg) intravenously at 1,2, and 4 weeks. There were 3 rabbits in each group. the entire cranium was removed with a reciprocating saw, without encroaching on the grafted areas.

\section{Evaluation}

\section{1) Radiographic evaluation}

Radiographs were taken of the rabbit calvaria in 
Table 1. The four groups randomly grafted at the calvarial defects.

\begin{tabular}{llll}
\hline \multicolumn{1}{c}{ Group } & $\mathrm{n}$ & \multicolumn{1}{c}{ Graft materials } & membrane \\
\hline control & 3 & no graft & PTFE (Tefgen) \\
EMD & 3 & Emdogain & PTFE (Tefgen) \\
DBBM & 3 & Bio-Oss & PTFE (Tefgen) \\
DBBM with EMD & 3 & Bio-Oss with Emdogain & PTFE (Tefgen) \\
\hline
\end{tabular}

Table 2. the bone density as determined radiographically

\begin{tabular}{lccc}
\hline 1 week & 2 week & 4 week & \\
\hline control & $0.15 \pm 0.06$ & $0.28 \pm 0.06$ & $0.37 \pm 0.12$ \\
EMD & $0.17 \pm 0.07$ & $0.31 \pm 0.07$ & $0.41 \pm 0.09$ \\
DBBM & $0.91 \pm 0.08^{*}$ & $1.05 \pm 0.17^{*}$ & $1.30 \pm 0.20^{*}$ \\
DBBM + EMD & $0.87 \pm 0.11^{*}$ & $1.16 \pm 0.06^{*}$ & $1.33 \pm 0.22^{*}$ \\
\hline
\end{tabular}

mean \pm SD (gram/square inch) analyzed by a ImageJ 1.31v software

statistical analysis : one-way ANOVA with fisher's Tukey test ; $\mathrm{P}<0.05$

*: Significantly different from corresponding control ( $\mathrm{P}<0.05)$

its entirety before histologic sections were performed. A aluminum step-wedge was used in each radiograph for comparison. The radiographs were scanned and images were analyzed with a ImageJ $1.31 \mathrm{v}$ software on a IBM computer.

\section{2) Histologic evaluation}

The rabbit calvarias were fixed in $4 \%$ paraformaldehyde, and decalcified in hydrochloric acid decalcifying solution (Fisher Scientific, Tustin, CA) at $4^{\circ} \mathrm{C}$ for 2-4 weeks. It was embedded in paraffin and cut into 6 um thickness. The sections were stained with $\mathrm{H} \& \mathrm{E}$ and observed by optical microscope.

\section{3) Statistical methods}

Numerical data was presented as mean plus one standard deviation. One way analysis of variance (ANOVA) with fisher's Tukey test was used for multiple comparisons to compare with the control. The probability level of $P<0.05$ was regarded as statistically significant.

\section{Results}

\section{Radiographic evaluation}

Figure 1 demonstrates the bone density as determined radiographically. There was a significant increase in bone density of DBBM group as compared with control and EMD group at 1,2 and 4 weeks $(\mathrm{P}<0.01)$. The results showed a significant increase in bone density when DBBM with EMD group were compared with control and EMD group at 1,2 , and 4 weeks $(\mathrm{P}<0.01)$. However significant increase was not seen at all time when control group was compared with EMD group (P>0.05). There was also no significant difference between DBBM and DBBM with EMD group at 1,2, and 4 weeks $(P>0.05)$.

\section{Histologic evaluation}

In all specimens, the defects were completely closed by the PTFE membrane and all group 


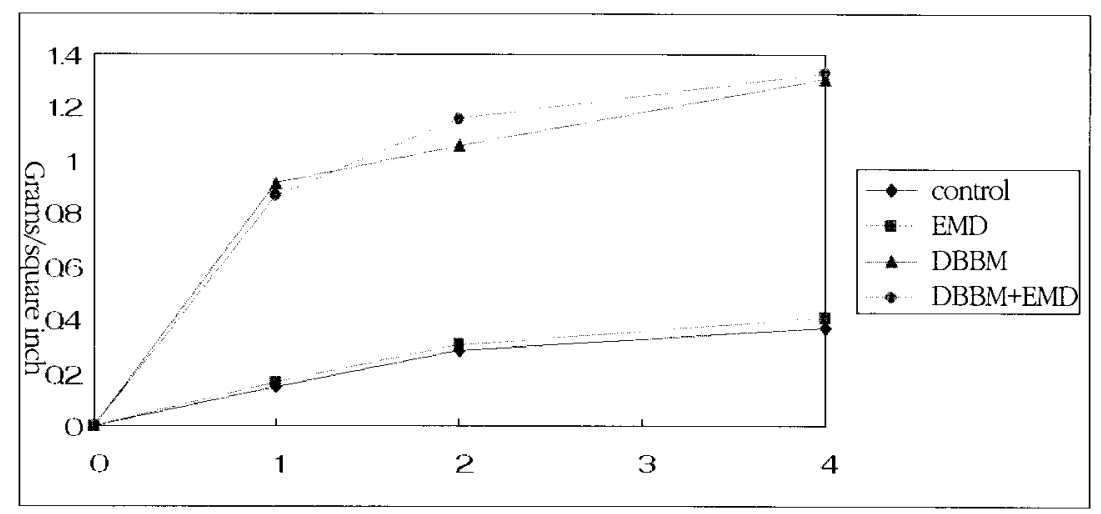

Figure 1. Amount of bone fill determined radiographically over the 4 weeks study period.

showed an increase in bone formation over time (Figure 4, 6, 9). The perforated areas were filled with granular tissue (Figure 4a,b). There was active osteoblastic activity and immature bone formation at the border of the defect in control and EMD group, it was similar histologically between control and EMD group (Figure 5a,b). A slightly increase in osteoblastic and osteoid layers were seen for DBBM group compared with control group (Figure $4 \mathrm{a}, \mathrm{c}$ ). Figure $4 \mathrm{c}$, d showed that the original thickness of bone at the defect site was maintained. There were osteoblastic and osteoid layers at the border of the defect and around deproteinized bovine bone material particles at DBBM and DBBM with EMD group, more osteoblastic and osteoid layers of DBBM with EMD group were seen than that of DBBM group (Figure $4 \mathrm{c}, \mathrm{d}, 5 \mathrm{c}, \mathrm{d}$ ).

Newly formed bone was seen at the border of the defect at control and EMD group and it extended further toward the central area of the defect (Figure $6 a, c)$. Newly formed bone within perforations in EMD group was more evident than that in control
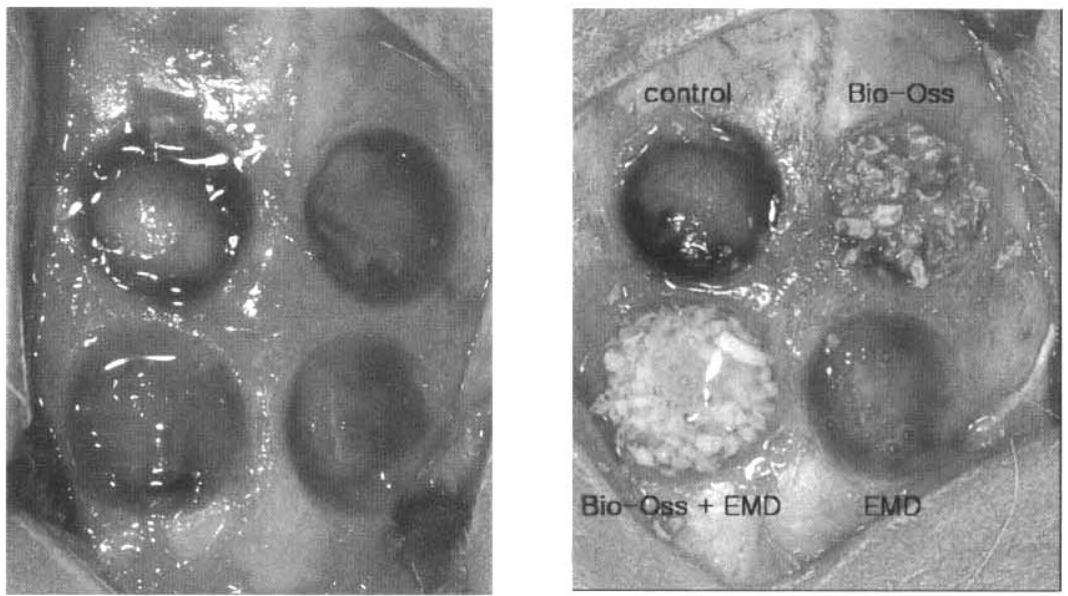

Figure 2. Photographs of the surgical sites

A, Rabbit calvaria with surgical sites prepared.

$\mathrm{B}$, Rabbit calvaria with surgical sites grafted 

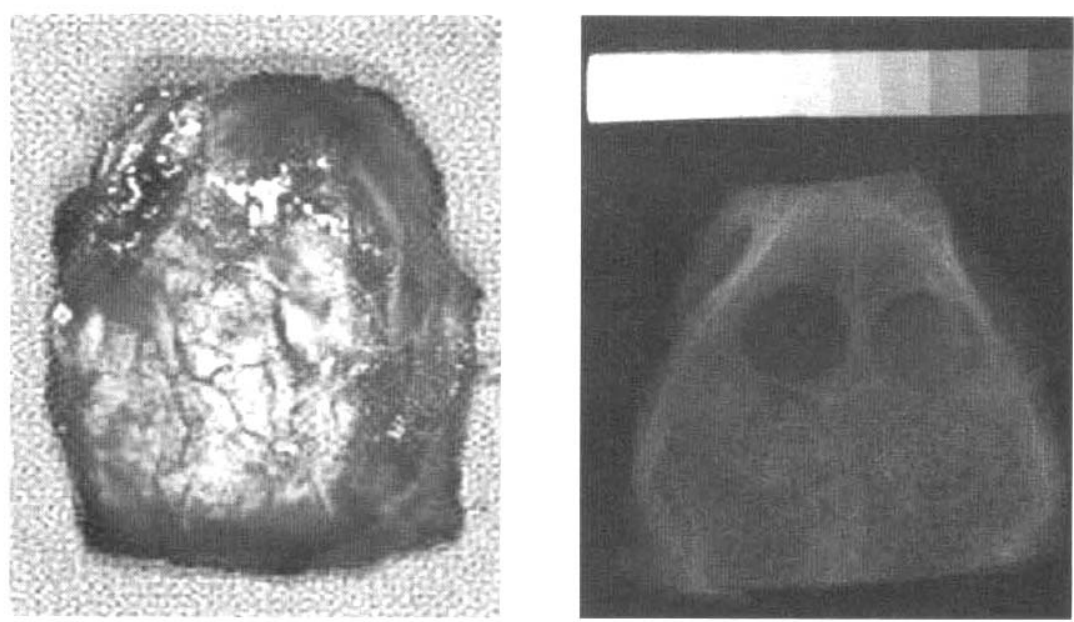

Figure 3. Gross and radiographic examination of surgical site

A, Rabbit calvaria harvested after 1,2 and 4 weeks of healing.

$B$, Radiograph of a rabbit calvaria with aluminium step wedge.

group at 2 weeks (Figure 7a,b). There was newly formed bone at the border of the defect and around deproteinized bovine bone material particles in DBBM and DBBM with EMD group (Figure 6c.d). There was slightly increase of newly formed bone at DBBM with EMD group as compared with DBBM group (Figure $7 \mathrm{c} . \mathrm{d}$ ).

All group showed an increase in bone formation at 4 weeks as compared with 1, 2 weeks (Figure $8 a, b, c, d)$. There was no difference at newly formed bone when control group was compared with EMD group (Figure 8a,b) and DBBM group was compared with DBBM with EMD group (Figure 8c.d). The individual particles of the bovine bone material were clearly identifiable and they were found to be surrounded by varying amounts of newly formed bone without being encapsulated by loose fibrous connective tissue in DBBM and DBBM with EMD group at all time.

Newly formed bone was not seen at the center of the defect in control group (Figure 9a). But there was newly formed bone around deproteinized bovine bone material particles at the center of the defect in DBBM group (Figure 9b).

\section{Discussion}

The present study has demonstrated the application of EMD in combination with deproteinized bovine bone materials results in the complete healing of defects in the calvaria of rabbits.

In the past decade, the use of barrier mambrane became a clinically well-documented and succeessful procedure 33,34$)$. The placement of a rigid, memebrane-like barrier created a secluded space adjacent to a bone surface. The barrier impeded cells originating from the surrounding soft tissues to invade the created space that becomes gradually filled with newly formed bone ${ }^{35,36)}$, which is stable on a long term basis ${ }^{37)}$. The placement of barrier membranes separating undesired tissue from the secluded wound space into which only cells with the potential of forming bone - are necessary to predictably close bone defects ${ }^{38)}$. When comparing bioabsorbable and non-resorbable membranes, better results with the non-resorbable membranes ${ }^{39}$ have 
been reported. Donos ${ }^{38)}$ reported that bioabsorbable membrane had no occlusive properties that long enough to allow bone formation within the defects. In this study, he showed that there were deproteinized bovine bone material particles encapsulated by loose fibrous connective tissue in the center of the rat calvarial defect covered by bioabsorbable membranes. In the present study, when non- resorbable membrane was placed to create a secluded space between the bony edges, the defects were completely closed at all group. There were deproteinized bovine bone material particles not encapsulated by loose fibrous connective tissue, but surrounded by newly formed bone at the center of the defect in DBBM and DBBM with EMD group. It supported that the placement of non-resorbable membranes are necessary to completely close the defects.

It has been reported that collapse of the barrier membranes into the bone defect compromises the amount of newly formed bone by eliminating the space, which is necessary for the bone to form ${ }^{35,40)}$. The mambranes used in GBR are often supported by mambranes-supporting materials including allografts, xenografts, and synthetic materials. Khalid ${ }^{41)}$ reported that the inorganic bovine bone materials posseessed the best potential of osteoconductive grafting material, followed by the biograss crystals and the hydroxyapatite particles respectively. In this study, he showed that the bovine bone materials showed significant increase in newly formed bone when compared to the no graft as a control. The collapse of the membrane could be avoided by using autogenous bone ${ }^{42,43}$ or Bovine bone material ${ }^{44)}$, such as the one used in this study. In the present study, there was more newly formed bone area in the DBBM group than in control group at 1 , 2 and 4 weeks. Indeed the use of bovine bone materials for the space maintenance under the membrane resulted in maintenance of the original thickness of bone at the calvarial defect.

Enamel matrix derivative has been developed as a clinical treatment to promote periodontal regeneration. It is derived from embryonal enamel of porcine origin, based on the high degree of homology between porcine and human enamel proteins ${ }^{16,45,46)}$. Amelogenins comprise $90 \%$ of the proteins present in EMD, the remaining 10\% are proline-rich non-amelogenins, including tuftelin, tuft protein, and various serum proteins, as well as, ameloblastin ${ }^{47)}$ and amelin ${ }^{48)}$.

In periodontal ligament (PDL) fibroblasts, EMD stimulates their migration, proliferation, differentiation, and enhances the expression of alkaline phosphatase activity, mineral nodule formation, and increases the autocrine release of cytokines such as transforming growth factor- $\beta$, IL- 6 and plateletderived growth factor $\mathrm{BB}^{27,49,50)}$. In gingival fibroblasts, EMD stimulates their proliferation ${ }^{51)}$. however, little is known about bone formation effect of EMD.

Concerning the biological effects of EMD on osteoblastic mesenchymal cells, EMD has been reported to stimulate the proliferation of preosteoblatic 2T9, OCT-1 and MC3T3-E1 cells, and enhance the differentiation of osteoblast-like osteosarcoma MG-63 cells ${ }^{49,50,52,53)}$. Enamel matrix derivative up-regulated osteopontin mRNA level and slightly enhanced BSP(bone sialoprotein) transcripts in these cell llines ${ }^{53)}$. In primary mouse osteoblasts, EMD enhanced the gene expression of collagen I $\alpha$, interleukin- 6 (IL-6) and prostaglandin $\mathrm{G} / \mathrm{H}$ synthase $2^{54)}$. Schwar ${ }^{52)}$ reported that EMD enhanced the Alkaline phosphatase activity of human-osteoblast cells. It has been reported that EMD increased the mineral nodule formation in mouse osteoblastic cells ${ }^{55}$. These results suggest that in osteoblastic and preosteoblastic cells EMD promotes proliferation, differentiation and enhances alkaline phosphatase 
activity and mineral nodule formation.

It has been reported that EMD is not osteoinductive but osteopromotive in vivo rat study ${ }^{29}$. Kawana and cowoker ${ }^{30)}$ reported that EMD exhibited osteopromotive effects on bone and medullary regeneration during wound healing of injured femurs and increased the initial trabecular bone formation. The trabecular bone area formed in EMD-applied femurs was significantly greater than that in PGA-applied control at 7 days. Sawae and cowoker ${ }^{31)}$ reported that EMD exhibited osteopromotive effects on bone regeneration during wound healing in rat parietal bone defects, at both 7 and 14 days post-operation, Mineralized tissue volume in EMD-applied bones was greater than that in PGA-applied control. In the present study DBBM and DBBM with EMD group showed a significant increase in newly formed bone when compared to control and EMD group at all time. There was a significant difference in histological analysis at 2 weeks when control was compared with EMD, there was a significant increase in newly formed bone surrounding bovine bone material at DBBM with EMD group as compared with DBBM group at 1,2 weeks.

Corneline and cowoker ${ }^{56)}$ reported that EMD implanted in $8 \mathrm{~mm}$ bone defects of rabbit tibia bone is fully resorbed after 4 to 8 weeks and dose not adversely affect bone formation and regeneration. Other investigations have shown controversial evidence on the inductive properties of the enamel matrix proteins ${ }^{29)}$. Donos and cowoker ${ }^{42)}$ reported that the predictability of bone formation in criticalsize defects of rat calvaria depends mainly on the presence or absence of barrier membranes(GBR). The combined use with deproteinized bovine bone mineral and/or enamel matrix proteins did not significantly enhance the potential for complete healing provided by the GBR procedure at 4 months. EMD failed to show any significant benefit in pro- moting new bone formation around titanium implants in a rabbit model ${ }^{57)}$ and dog model $^{58)}$. In the present study, there was no significant difference histologically at 4 weeks when EMD group was compared with control group and when DBBM with EMD group was compared with DBBM group.

These inconsistent results may be due to the different experimental systems and different animal employed in their experiments ${ }^{42}$. Experimental system has been described; First, defect site : tibia, femur, clavaria; Sencond, defect size : critical size defect and non-critical size defect; Third, evaluation period : long term data and short term data. The bioactive effects of EMD on bone wound healing and mineralized tissue formation depend on the local osseous environment where EMD has been applied $^{31)}$. These results suggest that EMD may positively influence initial bone wound healing, but EMD does not significant enhance the complete bone healing.

Digital subtraction radiography with aluminum step-wedge calibration showed a significant increase in bone density when DBBM, DBBM with EMD were compared to control and EMD group at all time. But radiographic assessment did not show any significant difference between DBBM and DBBM with EMD. The clinical significance of these data is difficult to determine because any radiopaque bone grafting material will look more dense on a radiograph.

In conclusion, this study has clearly demonstrated that the addition of DBBM with EMD in the rabbit cranial defect model was shown to be potentially beneficial at early wound healing. Deproteinized bovine bone materials had the good osteoconductive properties and served as a space maintainer successfully. Further studies are needed to evaluate the potential benefits of EMD in combination with various grafting materials such as autogenous bone, 
allograft, and alloplast graft. In vivo studies of EMD also are needed for the long term evaluation in wound healing.

\section{Conclusion}

The true periodontal regeneration is morphologic and functional reconstruction of periodontal tissue. It has been reported that EMD (Emdogain ${ }^{\circledR}$, Biora, Inc., Sweden) inhibited epithelial proliferation and encouraged periodontal tissue regeneration such as activation of biosynthesis of acellular cementum, periodontal ligament, and alveolar bone. In osteoblastic and preosteoblastic cells EMD promoted proliferation, differentiation and enhances alkaline phosphatase activity and mineral nodule formation. This study was to evaluate the effect of enamel matrix derivative (EMD) in combination with deproteinized bovine bone material (DBBM) in the early wound healing of rabbit calvarial defects.

Nine New Zealand white male rabbits between 2.8 and $4 \mathrm{~kg}$ were included in this randomized, blinded, prospective study. Four non-critical sized 8 $\mathrm{mm}$ defects were created by a trephine bur (external diameter : $8 \mathrm{~mm}$ ). The four calvarial defects were randomly grafted with DBBM (Bio-Oss ${ }^{\mathbb{B}}$, Geistlich, Wolhusen, Switzerland), DBBM with EMD, EMD alone, and no graft as a control. The Four defects were covered with nonresorbable PTFE membrane (Tefgen $^{\circledR}$, Lifecore Biomedical, Inc., U.S.A.). The wound was closed with resorbable suture materials. Rabbits were killed using phentobarbital $(100 \mathrm{mg} / \mathrm{kg})$ intravenously at 1,2 and 4 weeks. There were 3 rabbits in each group. the entire cranium was removed with a reciprocating saw, without encroaching on the grafted areas.

The results were as follows :

1. In radiographic evaluation, the results showed a significant increase in bone density when DBBM and DBBM with EMD group were compared with control and EMD group at 1,2, and 4 weeks ( $\mathrm{P}$ <0.01). However significant increase was not seen at all time when control group was compared with EMD group (P>0.05). There was also no significant difference between DBBM and DBBM with EMD group at 1,2 , and 4 weeks (P>0.05).

2. In histological evaluation, DBBM and DBBM with EMD group showed a significant increase in newly formed bone when compared to control and EMD group at 1,2 and 4 weeks. Newly formed bone within perforations in EMD group was more evident than that in control group at 2 weeks, A slightly increase in newly formed bone was seen for DBBM with EMD group compared with DBBM group at 1, 2 weeks.

In conclusion, this study has demonstrated that the addition of DBBM with EMD in the rabbit calvarial defect model was shown to be potentially beneficial at early wound healing. EMD might positively influence the early bone wound healing.

\section{References}

1. Lekholm, U. Adell, R. Lindhe, J.. "Marginal tissue reactions at osseointegrated titanium fixtures. A cross-sectional retropective study." Int J Oral Maxilofac Surg 1986;15:53-61

2. Reddi, A. H. Weintroub, S. Muthukumaran, N.. "Biologic principles of bone induction." Orthopedic Clinics of North Am. 1987;18:207212

3. Urist, M. R. . "Bone: formation by autoinfuction." Science 1965;150:893-899

4. Alberius, P. Dahlin, C. Linde, A. "A roll of osteopromotion in experimental bone grafting to the 
skull: a study in adult rats using a membrane technique" J Oral and Maxillofac Sug 1992;50:829-834

5. Jensen, S. S. Aaboe, M. Pinholt, E. M. et al.. "Tissue reaction and material characteristics of four bone substitutes." Int J Oral Maxillofac Implants 1996;11:55-66

6. Lundgren, A. K. Lundgren, D. Sennerby, L. et al.. "Augmentation of skull bone using a bioresorbable barrier supported by autologous bone graft. An intra individual study in the rabbit." Clinical Oral Implants Research 1997;8:90-95

7. Moy, P. K. Lundgren, S. Holmes, R. E. "Maxillary sinus augmentation: Histomorphometric analysis of graft materials for maxillary sinus floor augmentation." J Oral Maxillofac Surg 1993;51:857-862

8. Gross, J. S.. "Bone grafting materials for dental applications: A practical guide." Compend Contin Educ Dent 1997;18:1013-1018, 1020-1022, 1024

9.Zitzmann, N. U. Naef, R. Scharer, P.. "Resorbable versus nonresorbable membranes in combination with Bio-Oss for guided bone regeneration." Int J Oral Maxillofac Implants. 1997;12:844-852

10. Hammerle, C. H. F. Karring, T.. "Guided bone regeneration at oral implant sites." Periodontology 2000 1998;17:151-175

11. Hockers, T. Abensur, D. Valentini, P. et al.. "The Combined use of bioresorbable membranes and xenografts or autografts in the treatment of bone defects around implants. A study in beagle dogs." Clin Oral Implants Res. 1999;10:487-498

12. Yildirim, M. Spiekermann, H. Biesterfeld, S. et al.. "Maxillary sinus augmentation using xenogenic bone substitute material Bio-Oss in combination with venous blood:A histologic and histomorphometric study in humans." Clin Oral Implants Res 2000;11:217-229

13. Thaller, S. R. Hoyt, J. Borieson, K. et al.. "Reconstriction of calvarial defects with anorganic bovine bone mineral(Bio-Oss)in a rabbit model." J Ceaniofac Surg 1993;4:79-84

14. Slotte, C. Lundgren, D.. "Augmentation of calvarial tissue using non-permeable silicone domes and bovine bone mineral. An experimental study in the rat." Clinical oral Implants Res. 1999;10: 468-476

15. Fong, D. C. Slaby, I. Hammarstrom, L.. "Amylin, an enamel related protein, transcribed in the cells of epithelial root sheath." J Bone Miner Res 1996;11:892-898

16. Hammarstrom, L.. "Enamel matrix, cementum developmental and regeneration" J Clin periodontol 1997;24:678-684

17. Hammarstrom, L.. "The role of enamel matrix proteins in the development of cementum ant periodontal tissue." Ciba Found Symp 1997;205:246-260

18. Hammarstrom, L. Heijl, L, Gestrelius, S.. "Periodontal regeneration in a buccal dehiscence model in monkeys after application of enamel matrix protein." J Clin Periodontol 1997;24:669677

19. Slavkin, H. C. Bringas, P. Bessem, C. et al.. "Hertwig's epithelial root sheath differentiation and initial cementum and bone formation during long-term organ culture of mouse mandibular first molars using serum-less, chemically-defined medium." J Periodont Res 1988;23:28-40

20. Heiji, L. Heden, G. Svardstromm, G. et al.. "Enamel matrix derivate (EMDOGAIN) in the treatment of intrabony periodontal defects." J Clin Periodontol 1997;24:705-714

21. Mellonig, J. T.. "Enamel matrix derivative for periodontal reconstructive surgery:technique, 
clinical and histologic case report." Int J Periodontics Restorative Dent 1999;10:8-19

22. Ponterio, R. Wennstrom, J. Lindhe, J.. "The use of barrier membranes and enamel enamel matrix proteins in the treatment of angular bone defect." J Clin periodontol 1999;26:833-840

23. Sculean, A. Donos, N. Windisch, P. et al.. "Healing of human intrabony defects following treatment with enamel matrix protein or guided tissue generation." J Periodont Res 1999;34:310-332

24. Yukna, R. A. Mellonig, J. T.. "Histological evaluation of periodontal healing in humans following regenerative therapy with enamel matrix derivative." J Periodontol 2000;71:752-759

25. Heard, R. H. Mellonig, J. T. Brunsvold, M. A. et al.. "Clinical evaluation of wound healing following multiple exposure to enamel matrix protein derivative in the treatment of intrabony periodontal defects." J Periodontol 2000;71:1715-1721

26. Heden, G.. "A case report study of 72 consecutive Emdogaintreated intrabony periodontal defects: Clinical and radiographic finder after 1 year." Int J Periodontics Restorative Dent 2000;20:127-139

27. Hoang, A. M. Oates, T. W. Cochran, D. L.. "In vitro wound healing response to enamel matrix derivative." J Periodontol 2000;71:1270-1277

28. Schwartz, Z. Carnes, D. L. Pulliam, R. et al.. "Porcine enamel matrix derivative stimulates proliferation but not differentiation of preosteoblastic 2T9 cells, inhibits proliferation and stimulates differentiation of osteoblast-like MG63 cells, and increases proliferation and differentiation of normal human osteoblast NHOst cells. J Periodontol 2000;71:1287-1296

29. Boyan, B. D. Weesner, T. C. Lohmann, C. H., et al. " pocrine fetal enamel matrix derivate enhance bone formation induced by demineralized freeze derived bone allograft in vivo." J
Periodontol 2000;71:1278-1286

30. Kawana, F. Sawae, Y. Sahara, T.. "Porcine enamel matrix derivative enhances trabecular bone regeneration during wound healing of injured rat femur." Anat Rec 2001;264:438-446

31. Sawae, Y. Kawana, F. Sahara, T.. "Effects of enamel matrix derivative on mineralized tissue formation during bone wound healing in rat parietal bone defects." Electron Microsc 2002;51:413-423

32. Ripamonti, U. Reddi, A. H.. "Periodontal regeneration: potential role of bone morphgenetic proteins." J Periodontal Res. 1994;29:225-235

33. Lazzara RM.. "Immediate implant placement into extraction sites: the surgical and restorative advantages." Int J Periodont Restor Dent. 1989;9:333-343

34. Becker, W. Becker, B. Heldelsman, M. et al.. "Guided tissue regeneration for implants paced into extraction sockets :a study in dogs." J Periodontol 1991;62:703-709

35. Kostopoulos, L. Karring, T.. "Guided bone regeneration in mandibular defects in rats using a bioresorbable polymer" Clin Oral Imp Res 1994;5:66-74

36. Kostopoulos, L. Karring, T. Uragushi, R. . "Formation of jaw bone tuberosities using "Guided Tissue Regeneration". An experimental study in the rat." Clinical oral Implants Res. 1994;5:245-25337. Lioubavina, N. Kostopoulos, L. Karring, T.. "Long-term stability of jaw bone tuberosities produced according to the principle of "Guided Tissue Regeneration". An experimental study in the rat." Clinical oral Implants Res. 1999;10:477-486

38. Donos, N. Lang, P. Karoussis, K. et al.. " The effect of GBR in combination with deproteinized bovine bone mineral and/ or enamel matrix proteins on the healing of critical-size defects." 
Clinical oral Implants Res. 2004;15:101-111

39. Simion, M. Scarano, A. Gionso, L.. "Guided bone regeneration using resorbable and nonresorbable membranes:A comparative histologic stidy in humans." Int. J. Oral Maxillofac Implants 1996;11:735-742

40. Kostopoulos, L. Karring, T.. "Augmentation of rat mandible using the principle of guided tissue regeneration" Clin Oral Imp Res 1994;5:75-82

41. Khalid, A.. "Bone graft substitutes: A comparative qualitative histologic review of current osteoconductive grafting materials." Int J Oral Maxicclofac Implants 2001;16;105-114

42. Donos, N. Kostopoulos, L. Karring, T.. "Augmentation of the mandible by GTR and onlay cortical bone grafting. An experimental study in the rats" Clin Oral Imp Res 2002;13:175-184

43. Donos, N. Kostopoulos, L. Karring, T.. "Alveolar ridge augmentation by combinating autogenous mandibular bone grafts and non-resorbable membranes. An experimental study in the rats" Clin Oral Imp Res 2002;13:185-191

44. Hammerle, C. H. F. Chiantella, G. C. Karring, T. et al.. "The effect of a deproteinized bovine bone mineral on bone regeneration around titanium dental implants" Clin Oral Imp Res 1998;9:151-162

45. Brookes, S. J. Robinson, C. Kirkham, J. et al.. "Biochemistry and molecilar biology of amelogenin proteins of developing dental enamel" Arch Oral Biol 1995;20:1-14

46. Gestrelius, S. Andersson, C. Johansson, A. C.. "Formulation of enamel matrix derivative for surface coating. Kinetics and cell colonization" J Clin Periodontol 1997;24:678-684

47. Krebsbach, P. H. Lee, S. K. Matsuki, Y.. "Fulllength sequence, localization, and chromasomal mapping of ameloblastin" J Biol Chem 1996;271:4431-4435
48. Cerny, R. Slaby, I. Mammarstrom, L. et al.. "A novel gene expressed in rat ameloblasts codes for proteins with cell binding domains" J Bone Miner Res 1995;11:883-891

49. Van der Pauw, M. T. Van der Bos, T. Everts, V. et al.. "Enamel matrix derived potein stimulates attachment of periodontal ligament fibroblasts and enhances alkaline phosphatase activity and transforming growth factor $\beta 1$ release of periodontal ligament and gingival fibroblasts." J Periodontol 2000;71:31-43

50. Lyngstadaas, S. P. Lundberg, E. Ekdalh, H.. "Autocrine growth factors in human periodontal ligaments cells cultured on enamel matrix derivative." J Clin Periodontol 2001;28:181-188

51. Gurpinar, A. Onur, M. A. Cehreli, Z. C. et al.. "Effect of enamel matrix derivative on mouse fibroblasts and marrow stromal osteoblasts." J Biomater Appl. 2003;18;25-33

52. Schwartz, Z. Carnes, D. L. Pulliam, R.. "Porcine fetal enamel matrix derivative stimulates proliferation of osteoblast-like MG63 clls, and increases proliferation and differentiation of normal human osteoblast NHOst cells." J Periodontol 2000;71:1287-1296

53. Tokiyasu, Y. Takata, T. Sagin, E. et al.. "Enamel factors regulate expression of genes associated with cementoblast." J Periodontol 2000;71:18291839

54. Jiang, J. Fouad, A. F. Safavi, K. E. et al.. "Effects of enamel matrix derivative on gene expression of primary osteoblasts." Oral Surg. Oral med. Oral Pathol. Oral Radiol. Endod. 2001;91:95-100

55. Yoneda, S. Itoh, D. Kuroda, S. et al.. "The effects of enamel matrix derivative(EMD) on osteoblastic cells in culture and bone regeneration in a rat skull defect." J Periodont Res 2003;38;333-342

56. Corneline, R. Scarano, A. Piattelli, M. et al.. 
"Effects of Enamel matrix derivative (EMDOGAIN) on bone defects in rabbit tibias." J Oral implantol 2004;30;69-73

57. Stenport, V. Johansson, C.. "Enamel matrix derivative and titanium implants." J Clin Periodontol 2003;20:359-363
58. Casati, M. Z. Sallum, E. A. Nociti, F. H. Jr.. "Enamel matrix derivative and bone healing after guided bone regeneration in dehiscence-type defects around implants. A histomorphonetric study in dogs." J Periodontol 2002;73:789-796 


\section{사진부도 설명}

Figure 4, 5 (A) A light micrograph of control group at 1 week postoperatively : The perforated areas were filled with loose fibrous tissue. There were osteoblastic and osteoid layers from cortical bone margin.

(B) A light micrograph of EMD group at 1 week postoperatively : The perforated areas were filled with loose fibrous tissue. There were osteoblastic and osteoid layers from cortical bone margin.

(C) A light micrograph of DBBM group at 1 week postoperatively : There were osteoblastic and osteoid layers at the border of the defect and around deproteinized bovine bone material particles.

(D) A light micrograph of DBBM with EMD group at 1 week postoperatively : There were osteoblastic and osteoid layers at the border of the defect and around deproteinized bovine bone material particles.

Figure 6,7 (A) A light micrograph of control group at 2 week postoperatively: The perforated areas were filled with dense fibrous tissue. There was formation of new bone from cortical bone margin.

(B) A light micrograph of EMD group at 2 week postoperatively: The perforated areas were filled with dense fibrous tissue. There was formation of new bone from cortical bone margin.

(C) A light micrograph of DBBM group at 2 week postoperatively: There was formation of new bone from cortical bone margin. Osteoprogenitor cells and preosteoblasts were seen on the periphery of the graft materials.

(D) A light micrograph of DBBM with EMD group at 2 week postoperatively: There was formation of new bone from cortical bone margin. The graft materials have been incorporated into the newly formed bone matrix.

Figure 8 (A) A light micrograph of control group at 4 week postoperatively: The perforated areas were filled with dense fibrous tissue. There was formation of new bone from cortical bone margin.

(B) A light micrograph of EMD group at 4 week postoperatively: The perforated areas were filled with dense fibrous tissue. There was formation of new bone from cortical bone margin.

(C) A light micrograph of DBBM group at 4 week postoperatively: There was formation of new bone from cortical bone margin. The graft materials have been incorporated into the newly formed bone matrix.

(D) A light micrograph of DBBM with EMD group at 4 week postoperatively : There was formation of new bone from cortical bone margin. The graft materials have been incorporated into the newly formed bone matrix and were resorbed during the remodeling process.

Figure 9 (A) A light micrograph of control group at 4 week postoperatively : There was not formation of new bone in the center of the perforated areas.

(B) A light micrograph of DBBM group at 4 week postoperatively : There was newly formed bone around deproteinized bovine bone material particles in the center of the perforated areas. 
사진부도 (1)
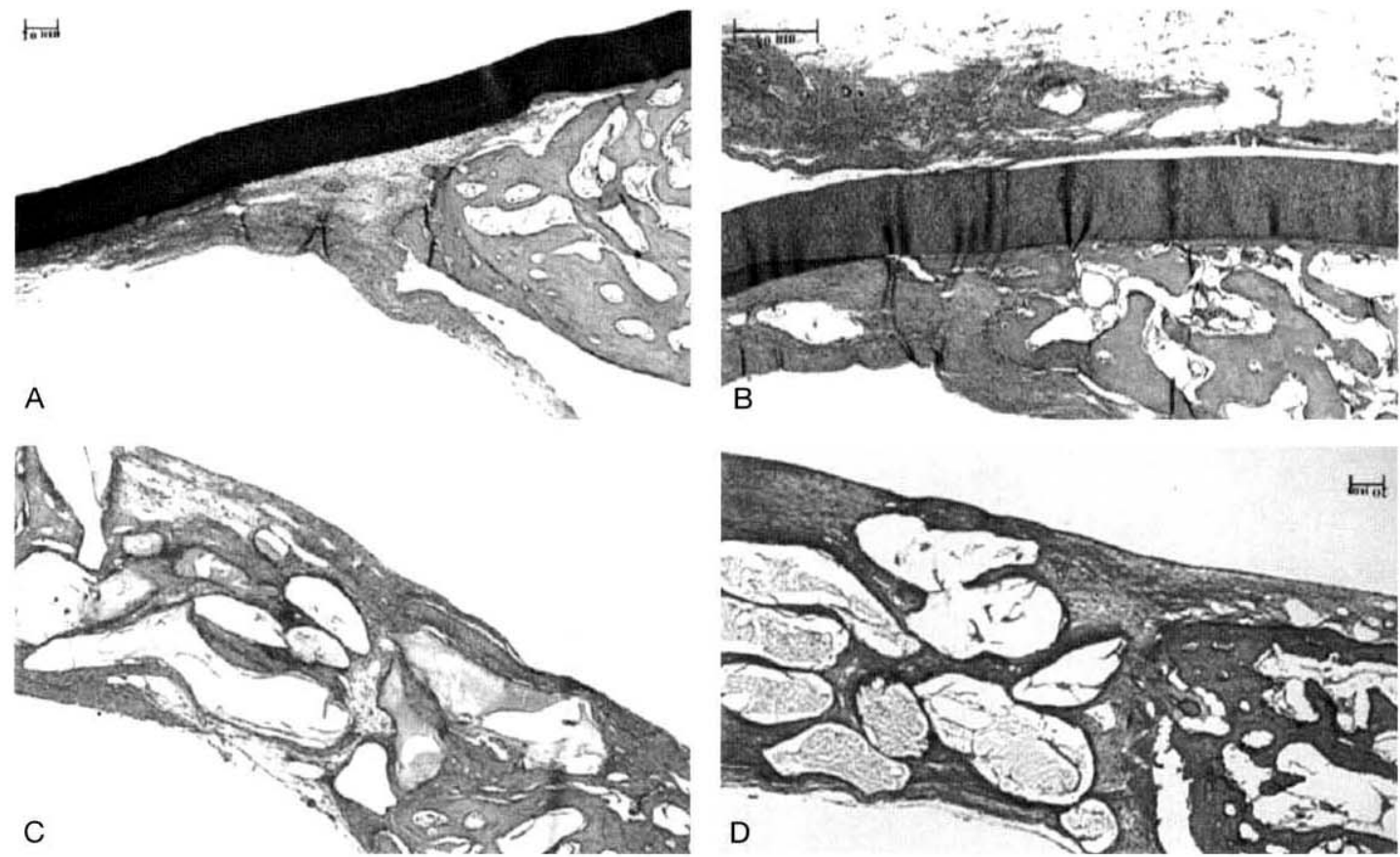

Figure 4. Light micrographs at 1 week postoperatively; control (A), EMD (B), DBBM (C), and DBBM with EMD (D). Haematoxylin and eosin staining, Magnification $\times 40$
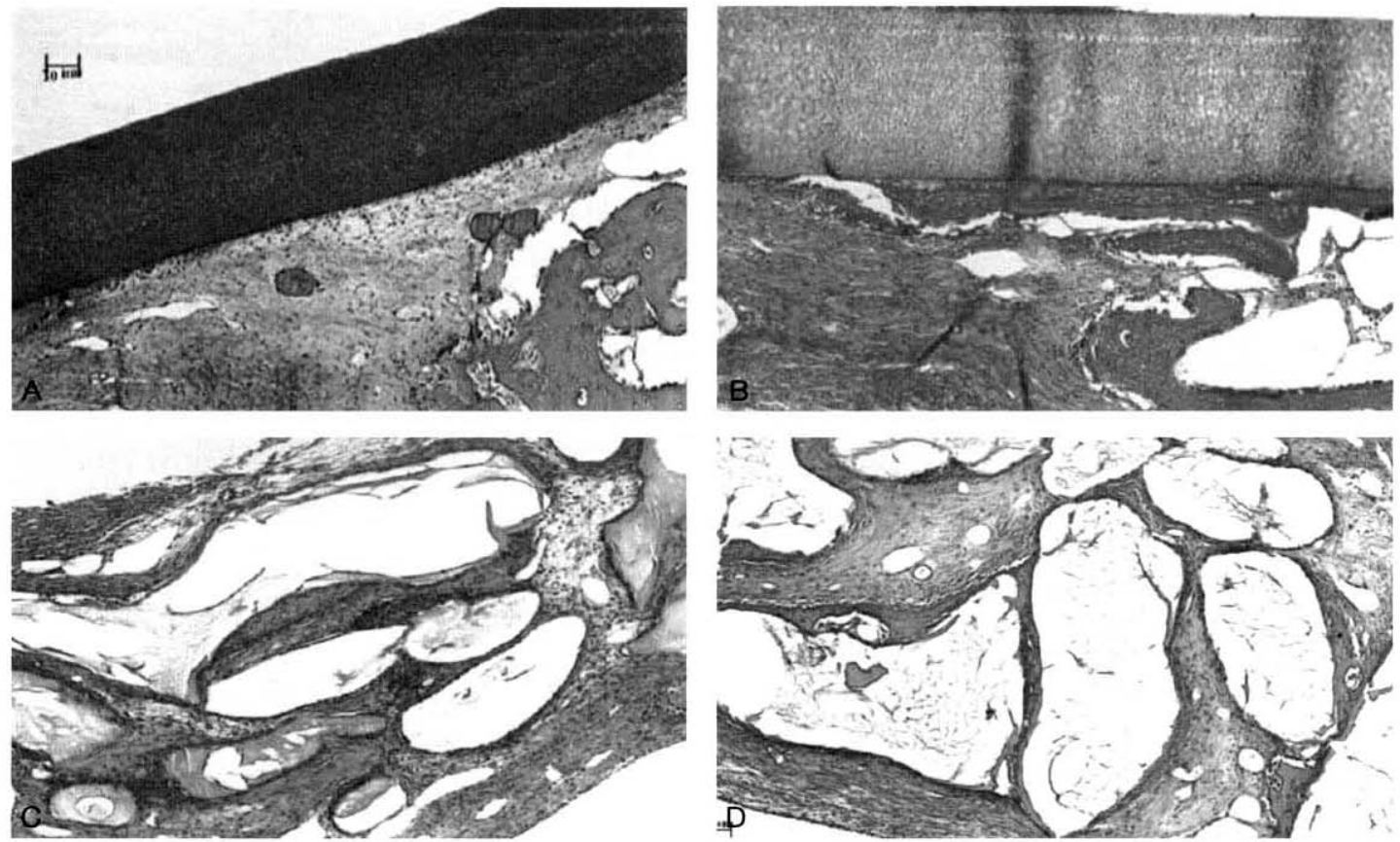

Figure 5. Light micrographs at 1 week postoperatively; control (A), EMD (B), DBBM (C), and DBBM with EMD (D). Haematoxylin and eosin staining, Magnification $\times 100$ 


\section{사진부도 (II)}



A

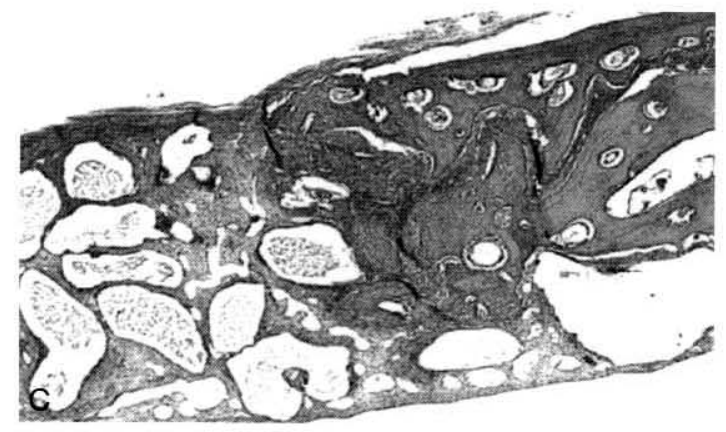

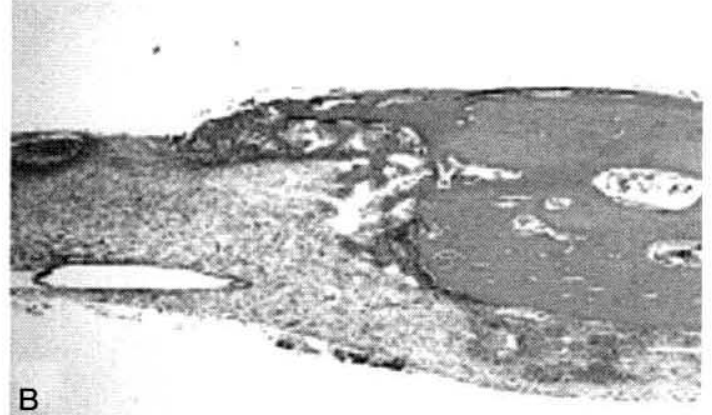

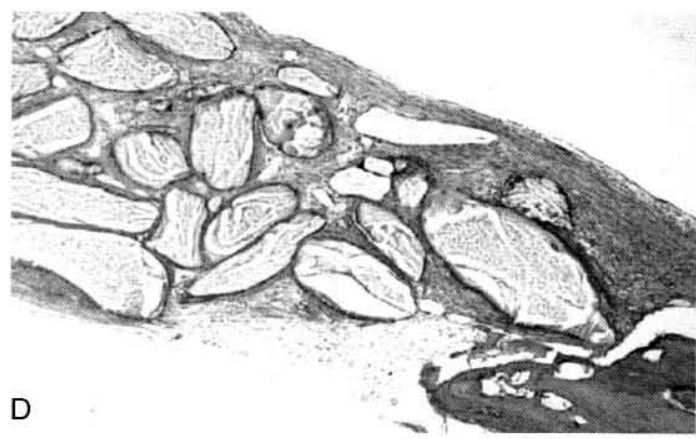

Figure 6. Light micrographs at 2 weeks postoperatively; control (A), EMD (B), DBBM (C), and DBBM with EMD (D). Haematoxylin and eosin staining, Magnification $\times 40$
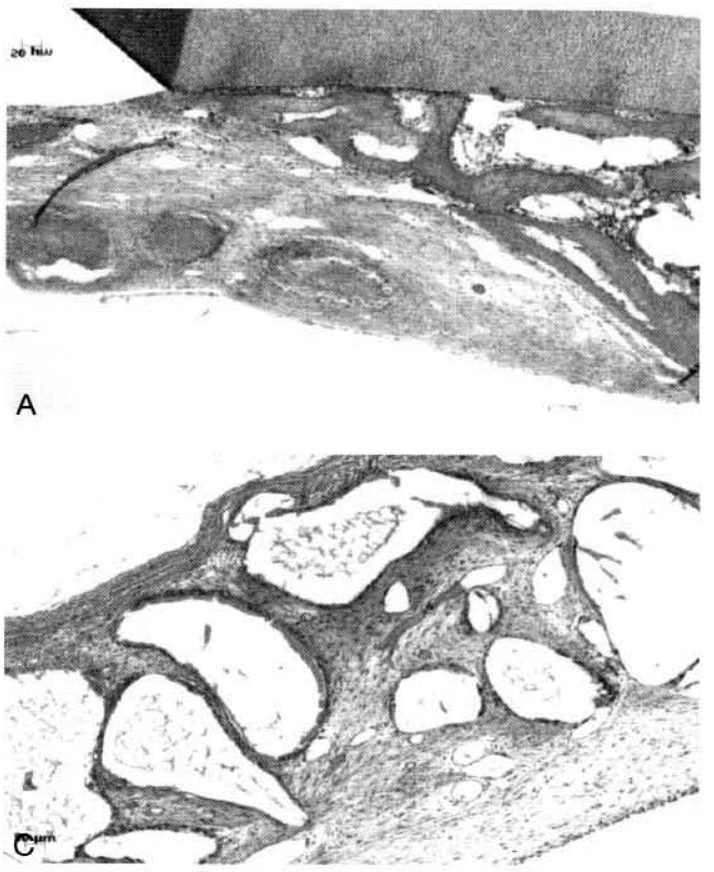
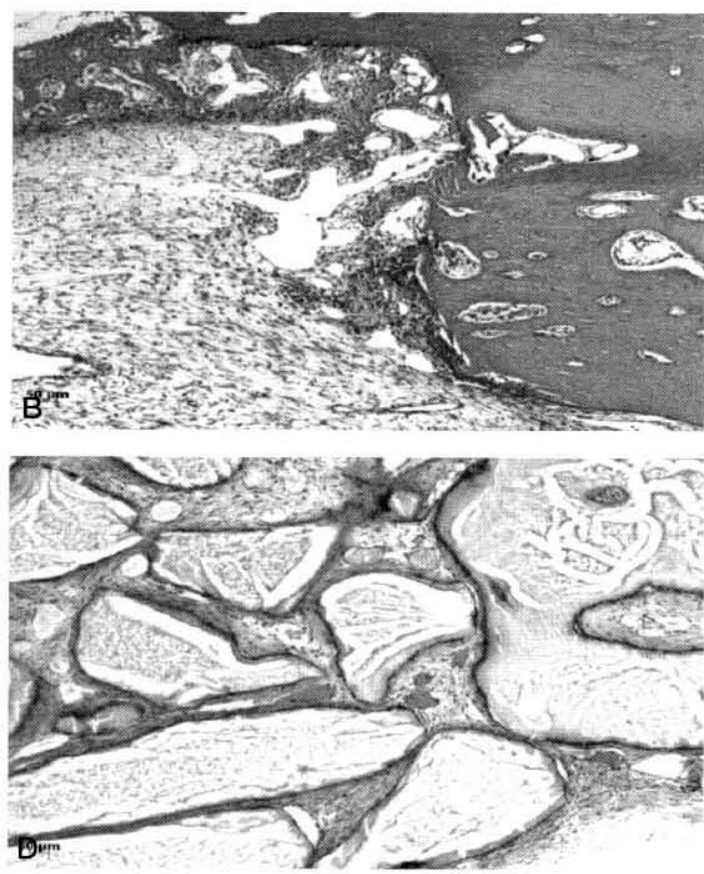

Figure 7. Light micrographs at 2 weeks postoperatively; control (A), EMD (B), DBBM (C), and DBBM with EMD (D). Haematoxylin and eosin staining, Magnification $\times 100$ 
사진부도 ( III )
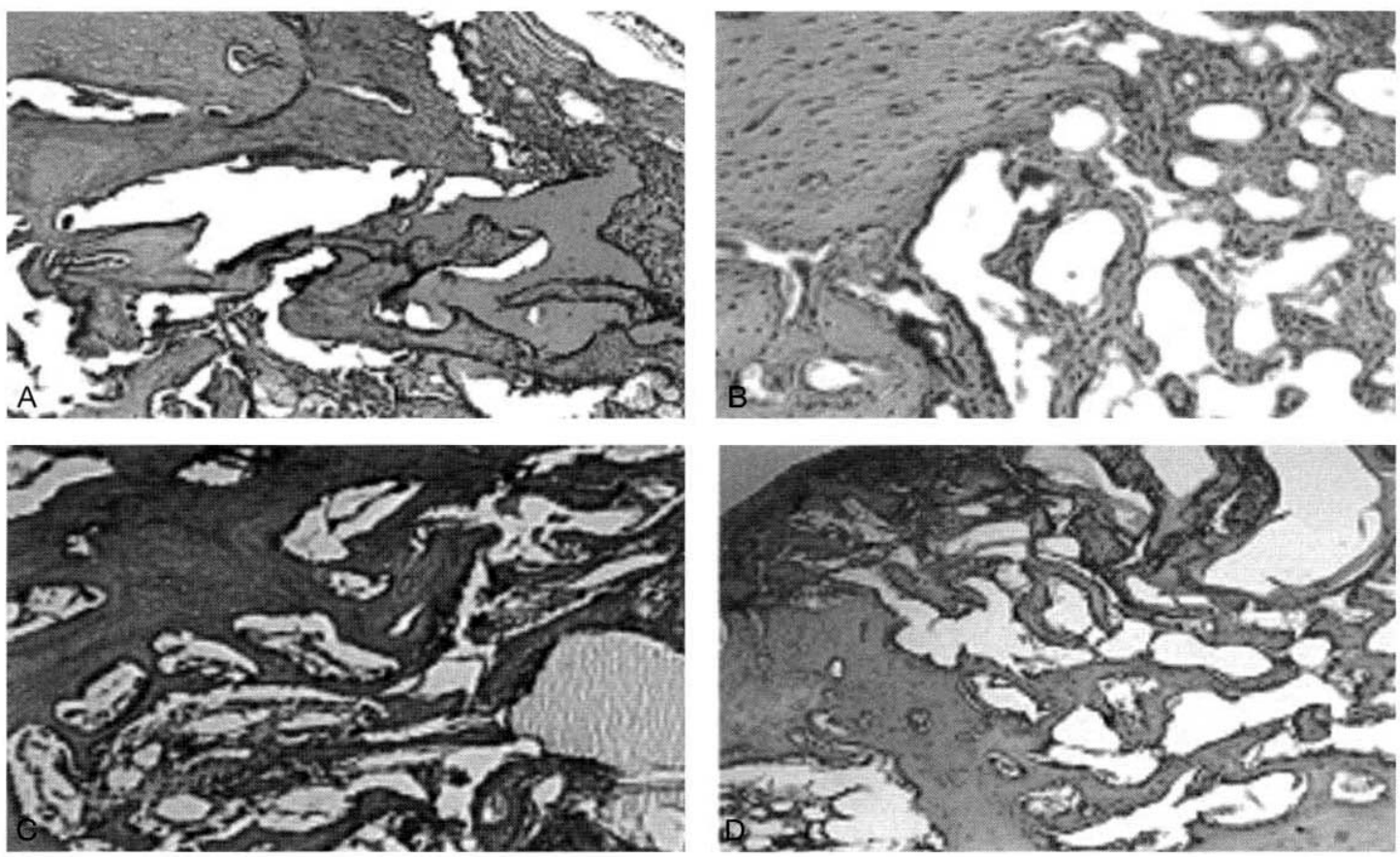

Figure 8. Light micrographs at 4 weeks postoperatively; control (A), EMD (B), DBBM (C), and DBBM with EMD (D). Haematoxylin and eosin staining, Magnification $\times 100$

atso

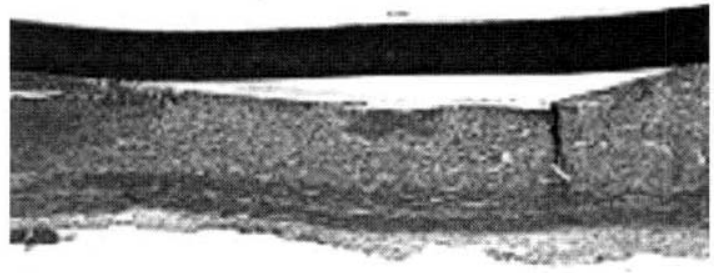

A

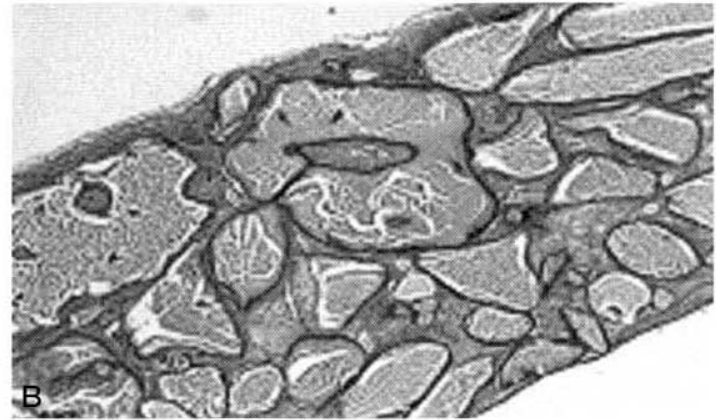

Figure 9. Light micrographs of the center of the defect at 4 weeks postoperatively; control (A), DBBM (B). Haematoxylin and eosin staining, Magnification $\times 40$ 
-국문초록-

\title{
법랑기질 단백질 유도체와 혼합된 이종골 이식재가 토끼 두개골 결손부 초기 치유에 미치는 영향
}

김유석 ${ }^{1}$, 장현선 ${ }^{1,4}$, 박주철 2,4 , 김흥중 3,4 , 이종우 ${ }^{1}$, 김종관 ${ }^{5,6}$, 김병옥 1,4

\author{
조선대학교 치과대학 치주과학교실1 \\ 조선대학교 치과대학 구강조직학교실2 \\ 조선대학교 치과대학 구강해부학교실3 \\ 조선대학교 치과대학 구강생물학연구소 4 \\ 연세대학교 치과대학 치주과학교실5 \\ 연세대학교 치과대학 치주조직 재생연구소 ${ }^{6}$
}

치주치료의 가장 중요한 목적은 상실된 치주조직의 형태적, 기능적 재건이다. 법랑기질 단백질 유도체 (enamel matrix derivative: $\mathrm{EMD}$ )는 치주 병소에 사용시 상피세포의 증식을 억제하며 치주인대 및 백악아세포 를 활성화시켜 무세포성 백악질 및 치주인대와 골조직의 생성을 유도한다고 보고되고 있다. 또한 법랑기질 단 백질 유도체는 골모세포의 증식 및 분화를 촉진시키며 alkaline phosphatase의 활성 및 mineralized nodule의 형성을 촉진시킨다고 보고되고 있다. 이에 본 연구에서는 토끼 두개골 결손부에 법랑기질 단백질 유도체와 이 종골 이식재를 이식한 후 골밀도를 방사선학적으로 분석하고, 신생골 형성 및 주변 조직 반응을 조직학적으로 관찰, 평가하고자 하였다.

토끼 두개골에 $6 \mathrm{~mm}$ trephine bur(외경 $8 \mathrm{~mm}$ )를 이용하여 경뇌막에 손상을 주지 않도록 하면서 4개의 결손 부를 형성하였다. 아무것도 이식하지 않은 군을 음성 대조군으로, 이종골 이식재 (Bio-Oss ${ }^{\circledR}$, Geistlich, Wolhusen, Switzerland)을 이식한 군을 양성 대조군으로 설정하였다. 법랑기질 단백질 유도체 (Emdogain ${ }^{\mathbb{R}}$, Biora, Inc, Sweden)만 이식한 군과 법랑기질 단백질 유도체와 이종골 이식재를 혼합하여 이식한 군을 실험군 으로 설정하였다. 각각의 재료를 이식한 후 비흡수성 차폐막 (Tefgen ${ }^{\circledR}$, Lifecore Biomedical, Inc., U.S.A.)을 위 치시키고 홉수성 봉합사로 일차봉합을 시행하였다. 각 군당 술 후 $1,2,4$ 주의 치유기간을 설정하였다. 동물을 희생시킨 후 두개골을 절제하여 먼저 방사선학적인 골밀도 측정을 시행한 후 $10 \%$ formalin에 고정한 후 통법에 따라 조직표본을 제작하여 광학현미경으로 관찰하였다.

1. 방사선학적인 평가에서 1,2 , 4 주에 대조군과 법랑기질 단백질 유도체만 이식한 군과 비교해 이종골 이식 재만 이식한 군과 이종골 이식재에 법랑기질 단백질 유도체를 이식한 군에서 더 큰 골의 밀도를 보이고 있 었다 $(P<0.01)$. 하지만, 동일한 시기에 대조군과 법랑기질 단백질 유도체만 이식한 군과의 차이는 발견할 수 없었으며 $(P>0.05)$, 이종골 이식재만 이식한 군과 이종골 이식재에 법랑기질 단백질 유도체를 이식한 군의 차이 또한 발견할 수 없었다 $(P>0.05)$.

2. 조직학적인 평가에서 1,2 , 4주에 대조군과 법랑기질 단백질 유도체만 이식한 군과 비교해 이종골 이식재 만 이식한 군과 이종골 이식재에 법랑기질 단백질 유도체를 이식한 군에서 골의 형성이 더 진행됨을 알 수 
있었다. 법랑기질 단백질 유도체만 이식한 군이 대조군보다 2주에서 더 많은 신생골을 볼 수 있었으며, 이 종골 이식재에 법랑기질 단백질 유도체를 이식한 군이 이종골 이식재만 이식한 군보다 1,2 주에서 더 많은 신생골을 관찰할 수 있었다.

이상의 결과에서 법랑기질 단백질 유도체는 토끼 두개골 결손부 치유단계에서 초기 골 형성을 촉진하는 것 으로 사료되며 골 이식시에 법랑기질 단백질 유도체를 적용하는 것은 유용한 술식으로 사료된다. 